\title{
Profile of under-five malnourished children admitted in a tribal medical college (RIMS) Adilabad, Telangana
}

\author{
Suryakant Mundlod ${ }^{1}$, Smita Thakkarwad ${ }^{2 *}$ \\ ${ }^{1,2}$ Associate Professor, ${ }^{1}$ Dept. of Pediatric, ${ }^{2}$ Dept. of OBGY, PCMC-PGI-YCMH Pimpri, Pune, Maharashtra, India \\ *Corresponding Author: Smita Thakkarwad \\ Email: dr_surya@rediffmail.com
}

\begin{abstract}
Introduction: Malnutrition is a major public health problem in a developing country like India, keeping this in mind a study was carried out to, 1). Find the proportion of under five children suffering from malnutrition among the under- five hospitalized children. 2). Find the Epidemiological factors responsible for development of malnutrition. 3). Find co-morbid illnesses associated with malnutrition.

Materials and Methods: This was a hospital based cross-sectional study, carried out in a tertiary care teaching hospital in Adilabad, telangana. All under-five children suffering from malnutrition were studied over a period of one month.

Results: Total number of under-five children suffering from malnutrition were 170 (83.33\%) Moderate \& severe/very severe malnutrition was statistically significant in children belongs to Upper-lower class socio-economic status according to modified 2007 KUPPUSWAMY classification.1) Illiteracy \& low educational status among mothers.2)Low birth weight $(<2.5 \mathrm{~kg})$ babies.3)Children who were not on exclusive breast feeding during their first 6 months of life.4)Children who were on improper complementary feeding practices.5)Low birth spacing.6)High birth order of children.7)Living in tribal \& rural area. Malnutrition is also higher in children, whose mothers were anemic $(74.11 \%)$ during pregnancy \& whose mothers are going to field work as daily labours \& farmers $(65.88 \%)$, due to low socio economic status. Among 170 malnourished children, 162(95.29\%) were suffering from ANEMIA. Among 170 malnourished cases the major comorbid illness is Diarrheal disease about 117(68.82\%).

Conclusion: A large proportion of hospitalized children were malnourished, came from rural, tribal \& urban slum areas \& this malnutrition is mainly because of low socio-economic status, illiteracy \& low educational status of mothers, improper breast feeding \& improper complementary feeding practices, low birth weight, low birth spacing \& high birth order, all these are statistically significant risk factors. And the major co-morbid illness associated with malnutrition is diarrheal illness \& anemia
\end{abstract}

Keywords: Hospital, Infant, Malnutrition, Morbidity, Preschool.

\section{Introduction}

Childhood malnutrition is an underlying cause in an estimated $35 \%$ of all deaths among children under five years of age. ${ }^{1}$ The prevalence of underweight children in India is among the highest in the world, and is nearly double that of Sub-Saharan Africa, the report says. The consequences of child undernutrition for morbidity and mortality are enormous - and there is, in addition, an appreciable impact of undernutrition on productivity so that a failure to invest in combating nutrition reduces potential economic growth. In India, with one of the highest percentages of undernourished children in the world, the situation is dire. Moreover, inequalities in undernutrition between demographic, socioeconomic, and geographic groups increased during the 1990s. More and better investments are needed if India is to reach the nutrition MDGs. Economic growth will not be enough. ${ }^{2}$

Keeping this in mind this study was carried out with the objective to find the proportion of under-five children suffering from malnutrition amongst the under-five hospitalized children and to study co-morbid illnesses and epidemiological factors associated with malnutrition amongst these children.

\section{Materials and Methods}

This was a cross-sectional study carried out in the pediatric ward of a tertiary care teaching hospital in Adilabad, India. All under-five children admitted in pediatric ward \&suffering from malnutrition were studied over a period of
1 month from 21 July 2016 to 21 august 2016. Since this was a short term project, the period of data collection limited to a period of 1 month. Ethical approval was taken from the institutional ethics committee before the commencement of study. Informed consent was taken from the parents/ legal guardian of the child. Study was conducted with the help of pre-tested proforma. Each child was examined clinically \&the important laboratory findings were noticed from the case sheet. Malnutrition was classified according to Indian academy of pediatrics (IAP) classification. This IAP classification based on weight-forage values. The standard used in this classification for reference population was the $50^{\text {th }}$ centile of Harvard standards.

A child was considered completely immunized for age if the child received all the doses as per Indian national immunization schedule. Low birth weight was defined as weight $<2.5 \mathrm{~kg}$. Socio-economic state was classified according to modified 2007 kuppuswamy classification. Proper complementary feeding is taken as initiation of CF at 7 months of age. Birth spacing about 24 months considered as normal.

All the under- five children admitted in pediatric ward over a period of 1 month \& suffering from malnutrition were included in this study.

Children of parents/ legal guardians not giving informed consent, children admitted in NICU (neonatal intensive care unit) /PICU (pediatric intensive care unit), 
and malnutrition secondary to the underlying chronic disease were excluded from the study.

Chi-square test was used to study the association between the variables.

' $p$ ' value of $<0.05$ was considered as statistically significant.

\section{Results}

1. Total under-five admissions in pediatric ward during the one month period $=204$ children.
2. Total number of under-five children diagnosed as malnourished $=170(83.33 \%)$, among them female children were $88(51.76 \%) \&$ male children were 82(48.23\%).

3. Moderate \&severe/ very severe malnutrition was observed in $129(75.88 \%)$ children, among them $64(72.72 \%)$ out of $88(51.76 \%)$ were female children \& $64(79.26 \%)$ out of $82(48.23 \%)$ were male children

Table 1: Showing association between malnutrition \& sex

\begin{tabular}{|c|c|c|c|c|c|c|c|}
\hline Sex & Mild & Moderate & Severe & Total & $\boldsymbol{X}^{2}$ chi square value & Degree of freedom & ' $\boldsymbol{p}$ ' value \\
\hline Male & 17 & 32 & 33 & 82 & 1.95, & & 2 \\
\cline { 1 - 4 } Female & 24 & 37 & 27 & 88 & & & \\
\cline { 1 - 5 } Total & 41 & 69 & 60 & 170 & & & \\
\hline
\end{tabular}

The association between malnutrition \& sex differentiation was not statistically significant.

Among 170 malnourished children 118(69.41\%) came from rural \& tribal area, 52(30.58\%) came from urban area. Among them nutritional status was as below shown in table,

Table 2: Showing association between malnutrition \& tribal and rural area

\begin{tabular}{|c|c|c|c|c|c|c|c|}
\hline Area of living & Mild & Moderate & $\begin{array}{c}\text { Severe/very } \\
\text { severe }\end{array}$ & Total & $\boldsymbol{X}^{\mathbf{2}}$ chi square value & $\begin{array}{c}\text { Degree of } \\
\text { freedom }\end{array}$ & ' $\boldsymbol{p}$ ' value \\
\hline Rural & 20 & 58 & 40 & 118 & 15.40, & 2, & 0.000 \\
\hline Urban & 21 & 11 & 20 & 52 & & & \\
\hline Total & 41 & 69 & 60 & 170 & & & \\
\hline
\end{tabular}

This association was statistically significant. It indicates that majority of malnourished children are living in tribal area.

Among 170 malnourished children, birth weight was available in 146 children, among them 41(87.23\%) were suffering from moderate \& severe/very severe malnutrition out of $47(27.64 \%)$ low birth weight $(<2.5 \mathrm{~kg})$ babies, $68(68.68 \%)$ children were suffering from moderate \& severe/very severe malnutrition out of $99(58.23 \%)$ normal birth weight $(>/=2.5 \mathrm{~kg})$ babies $\&$ remaining 24(14.11\%)children's birth weight not available (because of home deliveries), among them 20(83.33\%) children were suffering from moderate \& severe/very severe malnutrition. Among 170 malnourished children, educational status of mothers is as follows:

Table 3: Showing association between malnutrition \& educational status of other

\begin{tabular}{|c|c|c|c|c|c|c|c|}
\hline $\begin{array}{c}\text { Educational Status of } \\
\text { Mothers }\end{array}$ & mild & moderate & $\begin{array}{c}\text { Severe/very } \\
\text { severe }\end{array}$ & Total & $\begin{array}{c}X^{2} \text { chi square } \\
\text { value }\end{array}$ & $\begin{array}{l}\text { Degree of } \\
\text { freedom }\end{array}$ & 'p' value \\
\hline Illiterates & 10 & 24 & 27 & $61(35.8 \%)$ & \multirow[t]{6}{*}{15.3} & \multirow[t]{6}{*}{8} & \multirow[t]{6}{*}{0.054} \\
\hline $1^{0}$ school & 0 & 6 & 6 & $12(7.05 \%)$ & & & \\
\hline $2^{0}$ school & 18 & 29 & 19 & $66(38.82 \%)$ & & & \\
\hline Higher $2^{0}$ school & 6 & 7 & 5 & $19(11.17 \%)$ & & & \\
\hline Graduates & 7 & 3 & 3 & $13(7.64 \%)$ & & & \\
\hline Total & 41 & 69 & 60 & 170 & & & \\
\hline
\end{tabular}

Illiteracy \& low educational status in mothers, is statistically significant risk factor for development of malnutrition among under-five children

Table 4: Showing association between malnutrition \& birth weight

\begin{tabular}{|c|c|c|c|c|c|c|c|}
\hline $\begin{array}{c}\text { Birth } \\
\text { Weight }\end{array}$ & Mild & Moderate & $\begin{array}{c}\text { Severe/ } \\
\text { very severe }\end{array}$ & Total & $\begin{array}{c}X^{2} \text { chi square } \\
\text { value }\end{array}$ & $\begin{array}{c}\text { Degree of } \\
\text { freedom }\end{array}$ & 'p'value \\
\hline $\mathrm{LBW}(<2.5 \mathrm{~kg})$ & 6 & 18 & 23 & 47 & \multirow[t]{4}{*}{12.5} & \multirow[t]{4}{*}{4} & \multirow[t]{4}{*}{0.014} \\
\hline $\operatorname{Normal}(>/=2.5 \mathrm{~kg})$ & 31 & 43 & 25 & 99 & & & \\
\hline Not known & 4 & 8 & 12 & 24 & & & \\
\hline Total & 41 & 69 & 60 & 170 & & & \\
\hline
\end{tabular}


Low birth weight was a statistically significant risk factor for malnutrition.

Among 170 malnourished children, 42(24.70\%) children were first born children \& among remaining 128(75.29) malnourished children, proper birth spacing was seen in 32(25\%) children \& improper birth spacing was seen in 96(75\%) malnourished children, among them nutritional status was seen as below:

Table 5: Showing association between malnutrition \& birth spacing

\begin{tabular}{|c|c|c|c|c|c|c|c|}
\hline Birth spacing & Mild & moderate & $\begin{array}{c}\text { Severe/Very } \\
\text { severe }\end{array}$ & Total & $\begin{array}{c}\boldsymbol{X}^{\mathbf{2}} \text { chi square } \\
\text { value }\end{array}$ & $\begin{array}{c}\text { Degree of } \\
\text { freedom }\end{array}$ & $\begin{array}{c}\text { ' } \boldsymbol{p} \text { ' } \\
\text { value }\end{array}$ \\
\hline Proper & 10 & 08 & 14 & 32 & \multirow{2}{*}{15.64} & 2 & 0.000. \\
\cline { 1 - 4 } Improper (close) & 08 & 12 & 76 & 96 & & & \\
\hline Total & 18 & 20 & 90 & 128 & & & \\
\hline
\end{tabular}

The association was statistically significant. \& tells that low birth spacing also an important risk factor for development of malnutrition in under-5 children.

Among 170 malnourished children, $42(24.70 \%)$ children were $1^{\text {st }}$ born children, $42(24.70 \%)$ children were $2^{\text {nd }}$ born, $56(32.94 \%)$ children were $3^{\text {rd }}$ born, $20(11.76 \%)$ children were $4^{\text {th }}$ born $\& 10(5.88 \%)$ children were $5^{\text {th }}$ born children, among them nutritional was seen as below,

Table 6: Showing association between malnutrition \& order of birth

\begin{tabular}{|c|c|c|c|c|c|c|c|}
\hline Order of birth & mild & moderate & $\begin{array}{c}\text { Severe/ very } \\
\text { severe }\end{array}$ & Total & $\begin{array}{c}X^{2} \text { chi } \\
\text { square value }\end{array}$ & $\begin{array}{l}\text { Degree of } \\
\text { freedom }\end{array}$ & $\begin{array}{c}\text { 'p' } \\
\text { value }\end{array}$ \\
\hline $1^{\text {st }}$ & 20 & 12 & 10 & 42 & \multirow[t]{6}{*}{32.79} & \multirow[t]{6}{*}{08} & \multirow[t]{6}{*}{0.0001} \\
\hline $2^{\text {nd }}$ & 10 & 15 & 17 & 42 & & & \\
\hline $3^{\text {rd }}$ & 11 & 31 & 14 & 56 & & & \\
\hline $4^{\text {th }}$ & 00 & 08 & 12 & 20 & & & \\
\hline $5^{\text {th }}$ & 00 & 03 & 07 & 10 & & & \\
\hline Total & 41 & 69 & 60 & 170 & & & \\
\hline
\end{tabular}

This association was statistically significant. High birth order also an important risk factor.

Among 170 malnourished children, According modified (2007) KUPPUSWAMY CLASSIFICATION,123(72.35\%) children were belongs to upper-lower (IV) classification,37(21.17\%) children were belongs to lower-middle (III) classification, $10(6.47 \%)$ children were belongs to upper-middle (II) classification. Moderate \& severe/very severe malnutrition was noticed in $4(40 \%)$ children, among 10(5.88\%) malnourished children belongs to upper-middle (II) class. Moderate \& severe/very severe malnutrition was noticed in 26(70.27\%) children, among 37(21.76\%) malnourished children belongs to lower-middle (III) class. Moderate \& severe/very severe malnutrition was noticed in $99(80.48 \%)$ children, among $123(72.35 \%)$ malnourished children belongs to upper-lower (IV) class.

Table 7: Showing association between malnutrition \& socioeconomic status

\begin{tabular}{|c|c|c|c|c|c|c|c|}
\hline SES & Mild & moderate & $\begin{array}{c}\text { Severe/very } \\
\text { Severe }\end{array}$ & Total & $\begin{array}{c}\boldsymbol{X}^{2} \text { chi square } \\
\text { value }\end{array}$ & $\begin{array}{c}\text { Degree of } \\
\text { freedom }\end{array}$ & $\begin{array}{c}\text { 'p' } \\
\text { value }\end{array}$ \\
\hline Upper Middle(II) & 6 & 2 & 2 & 10 & \multirow{2}{*}{9.11} & 4 & 0.05 \\
Lower Middle(III) & 11 & 14 & 12 & 37 & & & \\
\cline { 1 - 5 } Upper Lower(IV) & 24 & 53 & 46 & 123 & & & \\
\hline Total & 41 & 69 & 60 & 170 & & & \\
\hline
\end{tabular}

So, low socio-economic status was a significant risk factor for development of malnutrition in under-five children.

Among 170 malnourished children, 113(66.47\%) children were not on exclusive breast feeding, among them 92(81.41\%) children were suffering from moderate \& severe/very severe malnutrition. 57(33.52\%) children were on exclusive breast feeding, among them $(64.91 \%)$ children were suffering from moderate \& severe/very severe malnutrition

Table 8: Showing association between malnutrition \& exclusive breast feeding

\begin{tabular}{|c|c|c|c|c|c|c|c|}
\hline EBF & Mild & Moderate & $\begin{array}{c}\text { Severe/very } \\
\text { severe }\end{array}$ & Total & $\begin{array}{c}\boldsymbol{X}^{\mathbf{2}} \text { chi square } \\
\text { value }\end{array}$ & $\begin{array}{c}\text { Degree of } \\
\text { freedom }\end{array}$ & $\begin{array}{c}\text { 'p' } \\
\text { value }\end{array}$ \\
\hline Given & 20 & 30 & 7 & 57 & 20.2 & 2 & 0.000 \\
\cline { 1 - 4 } Not Given & 21 & 39 & 53 & 113 & & & \\
\hline Total & 41 & 69 & 60 & 170 & & & \\
\hline
\end{tabular}


The association was statistically significant, so EBF is an important factor to prevent development of malnutrition among under-five children.

Among 168 malnourished children (as 2 malnourished children had 6 months of age),

$155(92.26 \%)$ children were not on proper complementary feeding practices among them $120(77.42 \%)$ were suffering from moderate \& severe/very severe malnutrition. $13(7.73 \%)$ children were on proper complementary feeding practices among them $7(53.84 \%)$ were suffering from moderate \& severe/very severe malnutrition

Table 8: Showing association between malnutrition \& Complementary Feeding Practices

\begin{tabular}{|c|c|c|c|c|c|c|c|}
\hline $\begin{array}{c}\text { Complementary } \\
\text { Feeding Practices }\end{array}$ & Mild & moderate & $\begin{array}{c}\text { Severe/very } \\
\text { severe }\end{array}$ & Total & $\begin{array}{c}\boldsymbol{X}^{2} \text { chi square } \\
\text { value }\end{array}$ & $\begin{array}{c}\text { Degree of } \\
\text { freedom }\end{array}$ & $\begin{array}{c}\text { 'p' } \\
\text { value }\end{array}$ \\
\hline Proper & 6 & 6 & 1 & 13 & 5.86 & 2 & 0.053 \\
\cline { 1 - 5 } Improper & 35 & 62 & 58 & 155 & & & \\
\hline Total & 41 & 68 & 59 & 168 & & & \\
\hline
\end{tabular}

The association was statistically significant. So, proper complimentary feeding practices are essential to prevent development of malnutrition in under-five children.

Among 170 malnourished children 162(95.29\%) have anemia \& 8(4.70\%) didn't have anemia. Among them $124(76.54 \%)$ children out of 162 anemic children were suffering from moderate \& severe/very severe malnutrition $\& 5(62.50 \%)$ children out of 8 not anemic children suffering from moderate $\&$ severe/very severe malnutrition.

So, in this study the most of malnutrition children were suffering from anemia $\&$ the association was clinically significant

Table 9: Showing association between malnutrition \& anemia in pregnancy

\begin{tabular}{|c|c|c|c|c|c|c|c|}
\hline Anemia & Mild & moderate & $\begin{array}{c}\text { Severe/very } \\
\text { severe }\end{array}$ & Total & $\begin{array}{c}\boldsymbol{X}^{\mathbf{2}} \text { chi square } \\
\text { value }\end{array}$ & $\begin{array}{c}\text { Degree of } \\
\text { freedom }\end{array}$ & $\begin{array}{c}\text { ' } \boldsymbol{p} \text { ' } \\
\text { value }\end{array}$ \\
\hline Yes & 38 & 66 & 58 & 162 & 0.895 & 2 & 0.639 \\
\cline { 1 - 5 } No & 3 & 3 & 2 & 8 & & & \\
\hline Total & 41 & 69 & 60 & 170 & & & \\
\hline
\end{tabular}

Among 170 malnourished children, 126(74.11\%) mothers had anemia during pregnancy, 9(5.29\%) were not anemic during pregnancy \& 35(20.58) mothers were not a booked \& immunized cases.

126 mothers had anemia during their pregnancy, among them $96(76.19 \%)$ children were suffering from moderate \& severe/very severe malnutrition.

9 mothers had anemia during their pregnancy, among them 6(66.66\%) children were suffering from moderate \& severe/very severe malnutrition.

35 mothers were not a booked \& immunized cases during their pregnancy, among them $27(77.14 \%)$ children were suffering from moderate $\&$ severe/very severe malnutrition.

The above values reflecting that, anemia in pregnancy is also an important factor for development of malnutrition in under-five children. This association was clinically significant..

Among 170 malnourished children, 123(72.35\%) children were completely immunized among them 95(77.23\%) children were suffering from moderate \& severe/very severe malnutrition. 47(27.64\%) children were not completely immunized among them 34(72.34\%) children were suffering from moderate \& severe/very severe malnutrition.

Table 10: Showing association between malnutrition \& immunization status of child

\begin{tabular}{|c|c|c|c|c|c|c|c|}
\hline $\begin{array}{c}\text { Immunization } \\
\text { Status }\end{array}$ & Mild & Moderate & $\begin{array}{c}\text { Severe/very } \\
\text { severe }\end{array}$ & Total & $\begin{array}{c}\boldsymbol{X}^{\mathbf{2}} \text { chi } \\
\text { square value }\end{array}$ & $\begin{array}{c}\text { Degree of } \\
\text { freedom }\end{array}$ & $\begin{array}{c}\text { 'p' } \\
\text { value }\end{array}$ \\
\hline Complete & 28 & 53 & 42 & 123 & 1.19 & 2 & 0.552 \\
\cline { 1 - 5 } Incomplete & 13 & 16 & 18 & 47 & & & \\
\cline { 1 - 5 } Total & 41 & 69 & 60 & 170 & & & \\
\hline
\end{tabular}

Association between immunization status and malnutrition was statistically insignificant.

\section{Discussion}

Total number of under-five children diagnosed as malnourished were $170(83.33 \%)$ out of the total 204 hospitalized children during period of 1 month. This reflects malnutrition is still an important \& major public health problem in India \& needs to be addressed.
In the present study moderate \& severe/very severe malnutrition was observed in $129(75.88 \%)$ children, among them females were $64(49.61 \%) \&$ males were $65(50.38 \%)$, this values reflects all children without sex differentiation were at almost equal (slightly higher among boys compared to girls) risk for development of malnutrition. In the region 
of this study, gender inequality not present. In a study carried out by ${ }^{1}$ Ngianga-Bakwin Kandala in children under the age of five in the Democratic Republic of Congo (DRC), the authors found that the prevalence of malnutrition was higher among boys compared to girls (46.1 versus 41.7 percent), \&malnutrition was linearly associated with maternal education (higher among children from noneducated mother, followed by children from mothers with primary education but lower among children from mothers with secondary or higher education: $49.8,47.0$ versus 35.2 percent $)^{11}$ Studies by Olwedo et al. ${ }^{9}$ in Uganda, Emina et al. ${ }^{7}$ in the Democratic Republic of Congo and Irena et al. ${ }^{16}$ in Zambia have suggested that under-nutrition is more prevalent among boys than among girls. ${ }^{17}$ Mahgoub and our study showed no difference in the proportions of boys and girls admitted for under-nutrition, in a study conducted by. ${ }^{18} \mathrm{Ngozi}$ S Ibeziako et al One hundred and twenty seven $(59.9 \%)$ were males while $85(40.1 \%)$ were females giving a male: female ratio of $1: 0.7 \&$ there was no statistically significant difference between the two genders This agrees with an earlier review in Maputo by ${ }^{13}$ Cartmell et al. ${ }^{24}$ Renuka et al study also showed that there was no statistically accepted difference was observed between boys $\&$ girls for malnutrition among under-five children.

Among 170 malnourished children 118(69.41\%) came from rural \& tribal area, 52(30.58\%) came from urban area. Among them nutritional status was, children suffering from moderate \& severe/very severe malnutrition were $98(83.05 \%) \& 31(59.61 \%)$ respectively, indicating that association was statistically significant \& in majority of cases living in rural area is acting as an important leading factor for other risk factors those are responsible for malnutrition in under-five children ${ }^{25}$ Jabalpur study among preschool children of Gond tribes of MP \& also ${ }^{24}$ Renuka et al study on tribal people shows that prevalence of malnutrition was high among children living in tribal area. Similarly prevalence of malnutrition was high in 1-5 year tribal children of Khammam District of Telangana. ${ }^{26}$

Moderate \&severe/very severe malnutrition was observed in $41(87.23 \%)$ children out of $47(27.60 \%)$ low birth weight $(<2.5 \mathrm{~kg})$ babies \& in $68(68.88 \%)$ children out of $99(58.23 \%)$ normal birth weight $(>/=2.5 \mathrm{~kg})$ babies, \& in $24(83.33 \%)$ children out of $20(14.11 \%)$ home delivery babies whose birth weight not known.

These values reflect low birth weight is an important risk factor for development of malnutrition in under-five children. In a study done by Ellen Van Poel et al in Ghana. ${ }^{2}$ children who were very small at birth had a higher probability to be stunted than children with normal size, \& socio-economic inequality is also an important risk factor for development of malnutrition in under-five children. A study done by Dhrubajyoti J Debnath and Chandrakant $V$ Parulekar tells that Postnatal growth failure is extremely common in the low birth weight infants. ${ }^{21}$

Among 170 malnourished children, educational status of mothers was as follows: 61(35.88\%) mothers were illiterate, among them $51(83.60 \%)$ children were suffering from moderate $\&$ severe/very severe malnutrition.12(7.05\%) mothers were educated up to $1^{0}$ school, among them $12(100 \%)$ children were suffering from moderate \& severe/very severe malnutrition $66(38.82 \%)$ mothers were educated up to $2^{0}$ school, among them $48(72.72 \%)$ children were suffering from moderate \& severe/very severe malnutrition $19(11.17 \%)$ mothers were educated up to higher $2^{0}$ school, among them $12(63.15 \%)$ children were suffering from moderate \& severe/very severe malnutrition $13(7.64 \%)$ mothers were educated up to graduation. among them $6(46.15 \%)$ children were suffering from moderate \& severe/very severe malnutrition.

These values reflect illiteracy \& low educational status in mothers is an important risk factor for development of malnutrition in under-five children. In a study carried out by Bharathi et $a l{ }^{3}$ it was observed that children with illiterate mothers, from low standard of living households are more prone to become malnourished. It is necessary to improve the rate of literacy, especially in women, to reduce the prevalence of malnutrition \& anemia among under-five children. $^{21}$ Dhrubajyoti J Debnath and Chandrakant V Parulekar study shows that children with illiterate mothers, from low standard of living are more prone to become malnourished. ${ }^{5}$ A Madondo, U E MacIntyre, B Ntuli study results show majority of malnourished children's mothers $(60 \%)$ were educated up to secondary school. A case-control study done by 4,10,14,8,12,15 Eskezyiaw Agedew showed that well educated mother's children were at statistically lower risk of being malnourished as compared to children of mother without education. In a case-control study in Bangladesh, the maternal illiteracy was associated with a fourfold increase in the risk of severe acute malnutrition in their children which is almost similar in this study. ${ }^{10}$

Among 170 malnourished children, 42(24.70\%) children were first born children \& among remaining 128(75.29) malnourished children, proper birth spacing was seen in $32(25 \%)$ children among them nutritional status was mild malnutrition seen in $10(31.25 \%)$ moderate malnutrition seen in $8(25 \%)$, severe malnutrition seen in $14(43.75 \%) \&$ improper birth spacing was seen in 96(75\%) malnourished children, among them nutritional status was mild malnutrition was seen in $8(8.33 \%)$, moderate malnutrition was seen in $12(12.5 \%)$ \& severe malnutrition was seen in $76(79.16 \%)$ children. this association was both clinically as well as statistically significant. A case-control study done by Eskezyiaw Agedew et al showed that preceding birth was also another important demographic variable affecting nutritional status of children. ${ }^{8}$ The significant and higher risk of malnutrition among children of lower preceding birth space, i.e., having a preceding birth interval of less than 24 months interval, could be due to mother already became anemic \& nutritionally deprived because of previous pregnancy \& she was also on breast feeding to her previous child. Close spacing may also have a health effect on the previous child, who may be prematurely weaned if the mother becomes pregnant again too early. As the preceding birth interval of the child decreases, the likelihood of being malnourished increases. Similarly low birth interval has 
been found as a risk factor for severe acute malnutrition in studies done in Sudan. ${ }^{12}$ finding of this study showed that the risk of malnutrition increases with age. As age of a child increased by one month the likelihood of being malnourished increased by 1.2 times. This may be an indication of either inappropriate food supplementation in quantity \&/or quality during the weaning and older period or exposure to diseases. Children in the youngest age group were at a significantly lower risk of being malnourished as compared with children in the older age groups. This low risk may also be due to the protective effect of breastfeeding, since almost all children are breastfed and most continue to breastfeed during their first year of life. These finding is consistent with studies conducted in the southern parts of Ethiopia ${ }^{4}$

Among 170 malnourished children, 42(24.70\%) children were $1^{\text {st }}$ born children, $42(24.70 \%)$ children were $2^{\text {nd }}$ born, $56(32.94 \%)$ children were $3^{\text {rd }}$ born, $20(11.76 \%)$ children were $4^{\text {th }}$ born $\& 10(5.88 \%)$ children were $5^{\text {th }}$ born children, among them nutritional was seen as mild malnutrition was $20,10,11(47.61 \%, 28.80 \%, 19.64 \%)$ moderate malnutrition was $12,15,31,8,3,9(28.57 \%$, $35.71 \%, 55.35 \%, 40 \%, 30 \%$,) severe malnutrition was 10 , $17,14,12,7(23.80 \%, 40.47 \%, 25 \%, 60 \%, 70 \%)$ seen respectively, this association was statistically significant indicates that higher the birth order was a significant risk factor for development of malnutrition in under-five children. A case-control study done by Eskezyiaw Agedew et al showed that the likelihood of being malnourished was 1.43 times higher among families who have increased number of children compared with low number of children in the house hold. The effect of a large family size with competition for food has been implicated as a risk factor for severe malnutrition in other studies as well. ${ }^{8}$

Among 170 malnourished children, According to modified (2007) KUPPUSWAMY CLASSIFICATION

$123(72.35 \%)$ children were belongs to upper-lower (IV) classification,

$37(21.17 \%)$ children were belongs to lower-middle (III) classification,

$10(6.47 \%)$ children were belong to upper-middle (II) classification

Moderate \& severe/very severe malnutrition was noticed in 4(40\%) children, among 10(5.88\%) malnourished children belongs to upper-middle (II) class.

Moderate \& severe/very severe malnutrition was noticed in 26(70.27\%) children, among 37(21.76\%) malnourished children belongs to lower-middle (III) class.

Moderate \& severe/very severe malnutrition was noticed in 99(80.48\%) children's, among 123(72.35\%) malnourished children belongs to upper-lower (IV) class. A study done by ${ }^{19}$. Lawrence et al showed that how rapidly will child malnutrition respond to income growth? This article explores that question using household survey data from 12 countries as well as data on malnutrition rates in a cross-section of countries since the 1970s. Both forms of analysis yield similar results. Increases in income at the household and national levels imply similar rates of reduction in malnutrition. A study conducted by Harold alderman et al the results show that better nutrition in children is associated with higher income..$^{20} \mathrm{In}$ a study done by Stalin $P$ et al Children of mothers who had completed higher secondary / graduation were better nourished than other children. Children belonging to lower socio-economic status were poorly nourished than those belong to upper socio-economic status. This association between nutritional status of children and socio-economic status was similar to the findings of previous studies. ${ }^{22,23}$

These values reflect low socio-economic status is an important risk factor for development of malnutrition in under-five children. Because of this low-socio economic state, most of the mothers $112(65.88 \%)$ out of 170 malnourished children are going to field work as farmers or labors, \& under-five child care was taken by grandparents, neiboures, \& elder siblings, which is not enough to prevent under-five malnutrition. A study done Eskezyiaw Agedew showed that Feeding less than three times a day more commonly observed in the severely malnourished group than the controls. ${ }^{8}$ It is usually associated with burden of workloads which prevent women from dedicating time to their children. This indicates that it is not only lack or shortage of food that predisposes young children to malnutrition but also lack of knowledge on appropriate infant and young child feeding and care practices. ${ }^{5} A$ Madondo, U E MacIntyre, B Ntuli study results show that $57.5 \%$ of the under-five malnourished children caregivers survived on less than 500 pula a month (equivalent to US\$65.00), indicating poor income in a family affects child's development. Under-five Malnutrition children Admitted at the University of In Nigeria Teaching Hospital, Enugu: a 10 year retrospective review by Ngozi S Ibeziako et al study review noted that malnutrition was more common among children from the lower social class $(69.4 \%)$ and those predominantly breast fed for three months or less (48.6\%) compared to exclusively breast fed children (18.9\%). ${ }^{18}$ The reason for this may be connected to the fact that poor families have low purchasing power for adequate nutritious foods for their families \&severelyunderweight children were more likely to have undernourished poorly educated teenage mothers, history of shorter duration of predominant breastfeeding, and fathers who were poorly educated and unskilled day-laborers ${ }^{15}$.Illiteracy on the other hand, may influence feeding practices.

Among 170 malnourished children, 113(66.47\%) children were not on exclusive breast feeding, among them $92(81.41 \%)$ children were suffering from moderate \& severe/very severe malnutrition. $57(33.52 \%)$ children were on exclusive breast feeding, among them (64.91\%) children were suffering from moderate \& severe/very severe malnutrition

These values reflect exclusive breast feeding is very essential to prevent malnutrition in under-five children. According to NFHS survey, less than half of children under 6 months of age are exclusively breast fed \& exclusive breast feeding drops to $28 \%$ for children aged 4-5 months.. 
A case-control study done by Eskezyiaw Agedew showed that, although most of the women continued to breast feed their babies well into the first year of life earlier starting of complementary feeds and discontinuation of breast feeding after then was common among the malnourished children and this was one of the most important factors to the development of malnutrition in the study population. This shows that malnutrition in early infancy may be attributed to the lack of exclusive breastfeeding. Besides, early complementary feeding that may expose infants to pathogens and increase their risk of infection which would also negatively affect their nutritional status. A study done in China showed that the introduction of other diet before the age of six months increased the prevalence of pneumonia and diarrheal diseases. ${ }^{14}$ Similarly a study in Kenya showed an increased risk of being underweight when complementary food was started early..$^{15}$ As a global public health recommendation, infants should be exclusively breastfeed for the first 6 months of life to achieve optimal growth, development and health. Thereafter to meet their evolving nutritional requirements, infants should receive nutritionally adequate and safe complementary foods while breastfeeding continues for up to two years of age or beyond. ${ }^{12}$

Among 168 malnourished children (as 2 malnourished children had 6 months of age), 155(92.26\%) children were not on proper complementary feeding practices among them $120(77.42 \%)$ were suffering from moderate \& severe/very severe malnutrition. 13(7.73\%) children were on proper complementary feeding practices among them 7(53.84\%) were suffering from moderate \& severe/very severe malnutrition.

These values reflect improper complimentary feeding practice was an important risk factor for development of malnutrition in under-five children. The age group 6 to 24 months accounted for $92.5 \%$ of the total number of children admitted for malnutrition in Nigerian and Zambian studies, an approximate $64 \%$ of admitted cases of malnutrition were less than two years while Cartmell et al. 4,14 documented a mean age of 21.7 months in the Maputo study. The reasons for the high number of cases of malnutrition among the age group 6 to 24 months could be due to a number of factors including low rate of exclusive breast feeding as well as poor weaning and feeding practices.

Among 170 malnourished children 162(95.29\%) have anemia \& 8(4.70\%) didn't have anemia. Among them $124(76.54 \%)$ children out of 162 anemic children were suffering from moderate \&severe/very severe malnutrition $\& 5(62.50 \%)$ children out of 8 not anemic children suffering from moderate $\&$ severe/very severe malnutrition.

So, in this study the most of malnutrition children were suffering from anemia \& the association was clinically significant. In a study of epidemiological \& clinical profile of hospitalized children with malnutrition in south India by ushadevi et al, ${ }^{6}$ Only $33 \%$ of malnourished children (cases) were exclusively breast fed. Among controls, $71 \%$ were exclusively breast fed for the first 6 mo after birth \& most cases had as associated infections (p 0.004) and anemia ( $\mathrm{p}<$ $0.001)$.

The major co-morbid illness associated with under-five malnutrition was diarrheal illness. in a study ofNgozi S Ibeziako et al. ${ }^{18}$ Cartmell et al. ${ }^{13}$ most common associated co-morbid illness was diarrhea seen in $72.7 \%$ of malnourished children. ${ }^{10}$ A prospective study carried out in Ethiopia found that malnourished children had significantly higher incidences of diarrheal diseases than their wellnourished counterparts, signifying that malnutrition is itself increased the risk of infection among under five children.

This study has limitations that being a short term research project carried out over a period of 1 month, the power of study is less due to small sample size\& there is a chance of disproportion between malnutrition among underfive children admitted in tertiary teaching hospital \& malnutrition among under-five children at community level.

However, the study was meticulously carried out \& the findings hold significance in a developing country like India, facing the terror of malnutrition.

\section{Conclusion}

From the above study malnutrition is still an important \& major public health problem in under-five children in India, the major epidemiological risk factors are

1. Low birth weight $(</=2.5 \mathrm{~kg})$,

2. Low socio-economic status,

3. Illiteracy \& low educational status among mothers,

4. Improper breast feeding \& complimentary feeding practice,

5. Anemia during pregnancy in mothers,

6. Improper birth spacing,

7. high birth order.,

8. living in tribal, rural \& urban slum areas.

$\&$ the most of malnourished children were anemic \& suffering from diarrheal illness

\section{Preventive measures}

By taking appropriate precautionary measures malnutrition is preventable:

\section{Individual level}

1. Proper hand washing before feeding to child,

2. Maintain sanitation \& hygiene in $\&$ around home,

3. Proper utilization of anganwadi facilities,

4. Kitchen gardening practice around home,

5. Provide appropriate ANC \& PNC care to mothers,

6. Health education to mothers \& family members regarding sanitation, importance of EBF, \& complimentary feeding practices in prevention of malnutrition in under-five children,

7. Adequate birth spacing should be present between two pregnancies,so, the mother will recover from previous pregnancy induced anemia \& she will ensure proper infant feeding \& complimentary feeding to the present child,

8. Vigorous EBF of infants for first 6 months of life should be promoted \& encouraged, 
9. Family planning after two children.

\section{At community level}

1. Health \& nutrition education,

2. Promotion of education \& literacy in community,

3. Growth should be monitored periodically on growth charts in anganwadi center,

4. Integrated primary health package should be available at anganwadi center,

5. Vigorous promotion of family planning to limit family size.

\section{At national level}

1. Nutritional supplementation,

2. Nutritional surveillance,

3. Nutritional planning,

\section{Source of Funding}

None.

\section{Conflict of Interest}

None.

\section{References}

1. Kandala NB, Madungu TP, Emaina JO, Nzita KD, Cappuccio FP. Malnutrition among under-five children in the Democratic Republic of Congo(DRC): Does geographic location matter? BMC Public Health 2011:11:26. (PMCID:PMC3111378) (Pub Med:21518428).

2. Poel EV, Hosseinpoor AR, Jehu-Appiah C, Vega J, Speybroeek N. Malnutrition \& the disproportional burden on the poor. Case Ghana Int J Equity Health 2007:06:21 (PMCID:PMC2245943) (Pub Med: 18045499)

3. Bharati S, Pal M, Chakrabarty S, Bharati P. Trends in socioeconomic and nutritional status of children younger than 6 years in India. Asia Pac J Public Health 2011;23:324 40. [PubMed: 21551133].Dhrubajyoti J Debnath and Chandrakant V Parulekar Profile of Under-Five Malnourished Children Admitted in a Tertiary Care Teaching Hospital in Pune, India. Int J Prev Med 2014;5(7): 882-6.

4. Yimer G. Malnutrition among children in southern Ethiopia. Ethiopian J Health Dev 2000;14: 282-292) \& Alemayehu Eshetu, Eskezyiaw Agedew. Determinant of Severe Acute Malnutrition among Children Aged 6-59 Months in Konso, Southern Ethiopia: Case Control Study. Quality Primary Care 2016;24(4):181-6.

5. Madondo A, MacIntyre UE, Ntuli B. The clinical and anthropometric profile of under-nourished children aged under 5 admitted to Nyangabgwe Referral Hospital in Botswana. South African J Child Health 2012;6(4):123-27.

6. Ushadevi, Sriram Krishnamurthy, Ballambattu Vishnu Bhat, Ajit Sahai. Epidemiologacal \& Clinical profile of Hospitalized Children With Moderate \&Severe Acute Malnutrition in South India. Indian J Pediatr 2015;82(6):504-51.

7. Irena $\mathrm{AH}, \mathrm{Mwambazi} \mathrm{M}$, Mulenga V. Diarrhoea is a major killer of children with severe acute malnutrition admitted to an in-patient set-up in Lusaka, Zambia. Nutr J 2011; 10: 110-115. Epidemiological and Clinical Profile of Hospitalized Children with Moderate and Severe Acute Malnutrition in South India Irena.

8. Eshetu A, Agedew E. Determinant of Severe Acute Malnutrition among Children Aged 6-59 Months in Konso, Southern Ethiopia: Case Control Study. Quality Primary Care 2016;24(4):181-86.
9. Emina JB, Kandala N, Inungu J. The effect of maternal education on child nutritional status in the Democratic Republic of the Congo. Nairobi, Kenya: African Population and Health Research Center, 2009.

10. Victora CG, Smith PG, Vaughan JP. Infant feeding and deaths due to diarrhea: A case control study. AM J Epidemiol 1989; 1290: 1032-1041.

11. Olwedo MA, Mworozi E, Bachou H, Orash GC. Factors associated with malnutrition among children in internally displaced persons' camps, Northern Uganda. Afr Health Sci 2008; 8: 244-252.

12. Coulter JB, Omer MI, Suliman GI, Moody JB, Macfarlane SB, Protein-energy malnutrition in Northern Sudan: Prevalence, socioeconomic factors and family background. Ann Trop Paediatr 1988; 8: 96-102.

13. Cartmell E, Natalal H, Francois I, Ferreira MH, Grahnquist L. Nutritional andclinical status of children admitted to the malnutrition ward, MaputoCentral Hospital: A Comparison of data from 2001 and 1983. J Trop Pediatr 2005;51(2):102-5

14. Wang X, Wang Y, Kang C. Feeding practices in 105 counties of rural China. Child Care Health Dev 2005;31:417-423.

15. Bloss E, Wainaina F, Bailey RC.Prevalence and predictors of underweight, stunting and wasting among children aged 5 and under in western Kenya. J trop Pediatr 2004; 50: 260-70.

16. Stefania Moramarco, Giulia Amerio, Clarice Ciarlantini, Jean Kasengele Chipoma, Matilda Kakungu Simpungwe, Karin Nielsen-Saines, Leonardo Palombi and Ersilia Buonomo. Community-Based Management of Child Malnutrition in Zambia. Int J Environ Res Public Health 2016;13:666

17. Mahgoub HM, Adam I. Morbidity and mortality of severe malnutrition among Sudanese children in New Halfa Hospital, Eastern Sudan. Trans R Soc Trop Med Hyg 2012;106: 66-8.

18. Agozie C Ubesi, Ngozi S Ibeziako, Chika I Ndiokwelu Chinyeaka M Uzoka and Chinelo A Nwafor. Under-five Protein Energy Malnutrition Admitted at the University of In Nigeria Teaching Hospital, Enugu: a 10 year retrospective review Ubesie et al. Nutrition Journal 2012.

19. Gillespie SR, Lawrence $H$. The relationship between nutrition and the Millennium Development Goals: a strategic review of the scope for DFID's influencing role. IFPRI

Report. Washington: International Food Policy Research Institute, 2003.

20. Harold Alderman, John Hoddinott and Bill Kinsey Long term consequences of early childhood malnutrition. Oxf Econ Pap 2006;58(3):450-74.doi: 10.1093/oep/gp1008First published online: May 2, 2006.

21. Dhrubajyoti J Debnath and Chandrakant V Parulekar Profile of Under-Five Malnourished Children Admitted in a Tertiary Care Teaching Hospital in Pune, India. Int J Prev Med 2014;5(7): 882-6.

22. Stalin P, Joy Bazroy, Dinesh Dimri, Sathish Sathyanarayanan, prevalence of underweight $\&$ its risk factors among under 5 children in a rural area of Kancheepuram district in Tamilnadu, India. IOSR J Dent Med Sci (IOSR-JDMS) 2013;3(6):71-74. PP.ISSN: 2279-0853, ISBN: 2279-0861. V

23. Chowdhury SD, Chakraborty T and Ghosh T. Prevalence of Undernutrition in Santal children of Puruliya District, West Bengal. Indian Pediatr 2008;45(1):43-6.

24. Manjunath R, J Kumar K, and Gangadhar MR Malnutrition Among Under-Five Children of Kadukuruba Tribe: Need to Reach the Unreached. J Clin Diagn Res 2014;8(7): JC01-JC04.

25. Rao VG, Rajeev Y, Dolla CK, Kumar S, Bhondeley MK, Ukey $\mathrm{M}$ et al. Undernutrition and childhood morbidities among tribal preschool children. Indian J Med Res 2005;122: 43-7.

26. Laxmaiah A, Rao MK, Kumar H, Arlappa K, Venkaiah, Brahmam GNV. Diet and Nutritional status of Tribal 
population in ITDA Project areas of Khammam District,

Andhra Pradesh. J Hum Ecol 2007;21(2):79-86.

How to cite this article: Mundlod S, Thakkarwad S. Profile of under-five malnourished children admitted in a tribal medical college (RIMS) Adilabad, Telangana. Int $J$ Med Paediatr Oncol 2019;5(4):129-37. 